\title{
TILLAGE REDUCTION IN CENTRAL EAST ITALY
}

Laureti, D.* and Pieri, S.

CRA Experimental Industrial Crops Institute, via Cagiata, 90, 60027 Osimo (AN) Italy

Received: October 10, 2006 Accepted: May 15, 2007

\section{SUMMARY}

The effect of several soil tillage methods (plowing at a depth of $20-25 \mathrm{~cm}$, chiseling at $30 \mathrm{~cm}$ and plowing at $20 \mathrm{~cm}$ plus sub-soiling at $50 \mathrm{~cm}$ factorially combined with three biennial rotations (wheat-sugarbeet; wheat-sorghum; wheat-sunflower) were studied between 2000 and 2005. Sugarbeet confirmed the supposed increased need for deep tillage, whereas sorghum and sunflower were less sensitive. With dry soil chiseling was enough to prepare a seed bed compared with plowing plus sub-soiling, whereas with moist soil, shallow plowing gave the best results in sorghum but not in sugarbeet. Plowing plus sub-soiling requires more energy and it could be justified only in sugarbeet. Wheat yielded better after sugarbeet and sunflower than after sorghum. Minimum tillage was as efficient as shallow plowing for wheat seed bed preparation.

Key words: sunflower, soil tillage methods, sugar beet, sorghum

\section{INTRODUCTION}

The extensive experimental activity on seedbed preparation has confirmed the use of minimum tillage on cropping wheat in Italy, whereas in summer crops the practice is still under debate especially in function of the crop. Reduced tillage is suggested for shallow rooted crops, whereas a little deeper is recommended for deep rooted crops (sugarbeet, carrot, etc.). The main tillage goal is, among others, to increase soil macro-porosity that allows better water infiltration, root development, nitrification, soil respiration, etc.

Wheat yield is influenced by rotation (Laureti and Pieri, 2004; Norwood, 2000; Roth et al., 2000) and in recent years growers have preferred to cultivate sugarbeet instead of sunflower even if the yield of the cereal following it is similar.

\footnotetext{
* Corresponding author: domenico.laureti@entecra.it
} 
To contribute to the knowledge of tillage and rotation effects on crop yield, an experiment was carried out in the years 2000-2005 in East Central Italy.

\section{MATERIALS AND METHODS}

Three tillage methods (plowing at a depth of $20-25 \mathrm{~cm}$, chiseling at $30 \mathrm{~cm}$ and plowing at $20 \mathrm{~cm}$ plus sub-soiling at $50 \mathrm{~cm}$ ) were evaluated from 2000 to $2005 \mathrm{on}$ an Acquic Xerorthent, fine, mixed, calcareous, semiactive, mesic soil. The tillage methods were factorially combined with three biennial rotations (wheat-sugarbeet; wheat-sorghum; wheat-sunflower) replicated four times. Tillage for wheat consisted of plowing at $25 \mathrm{~cm}$ in all years and minimum tillage the last three years.

Crops were established in the winter of 2000 in chiselled soil and the first differential tillage started in the summer of the same year. Results of the last five years are reported where there was a tillage effect.
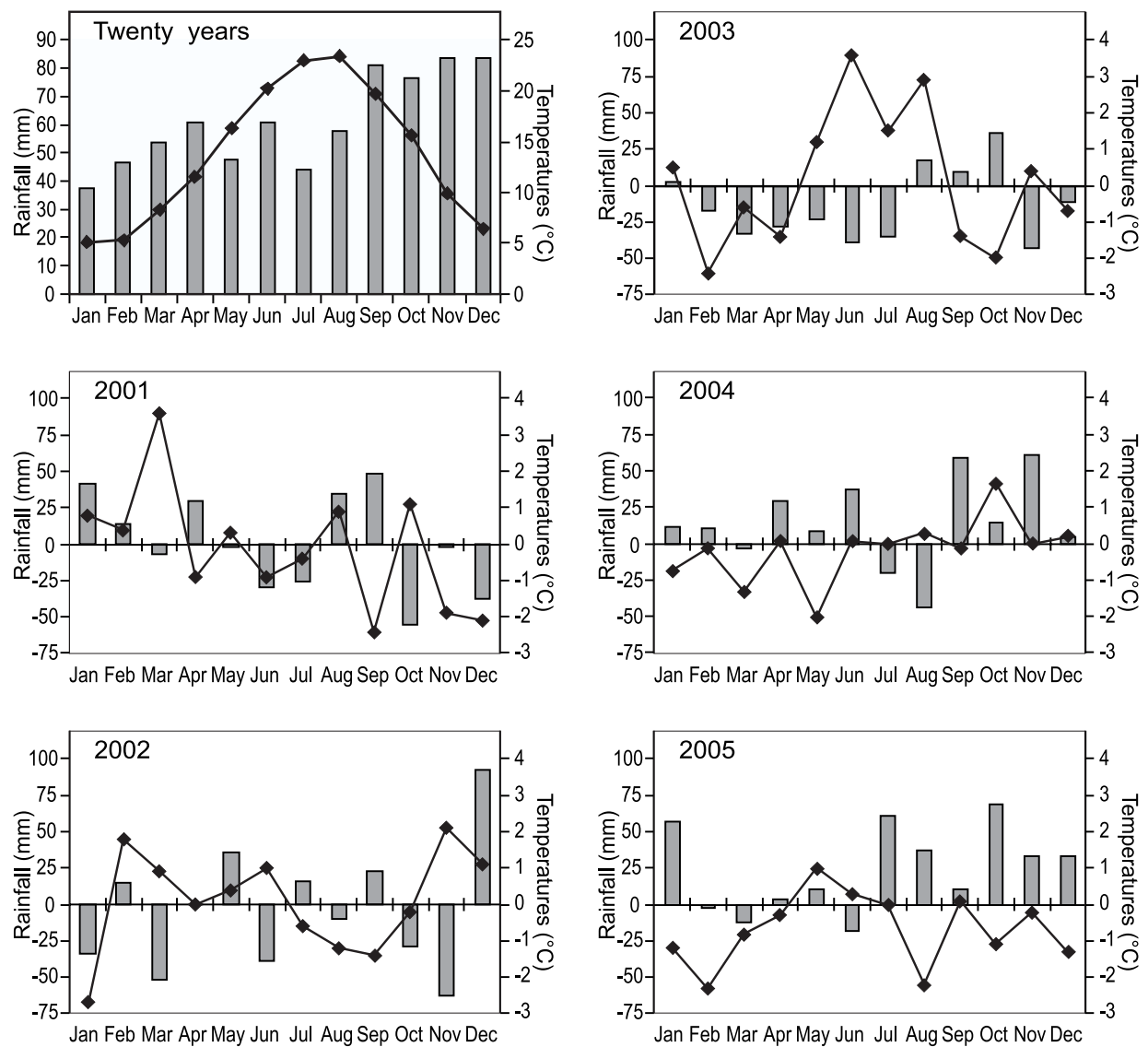

Figure 1: Rainfall ( $\mathrm{mm}$ ) and mean temperatures $\left({ }^{\circ} \mathrm{C}\right)$ of the experimental years compared with the previous twenty-year period. 


\section{Weather conditions}

In the five years reported, rainfall and temperature were very different (Figure 1). Rainfall in April and June (of interest for wheat) was nearly always below the average, and in June-August (of summer crop and tillage interest) it was often below the average, reaching the lowest values in 2003 when the highest deficit occurred. Rainfall significantly influenced crop results, directly and throughout the effects on tillage.

Temperatures were similar to the 20 year average, with values higher or lower according to low or no rainfall.

\section{Effects of the year}

This factor was significant for all traits recorded, confirming that results are significantly influenced by rainfall during the year of cropping and during the year of tillage. Effects of the year were reported when combined with the other factors evaluated.

\section{Tillage effects on summer crops}

\section{Sugarbeet}

Tillage resulted in significant differences in root yield only in 2002 (Table 1) when plowing plus sub-soiling showed better values than shallow plowing but not better than chiseling. Larger roots had lower sugar content so no difference in sugar yield was found in 2002 .

Table 1: Tillage effects on sugarbeet combined with the year*

\begin{tabular}{|c|c|c|c|c|c|c|c|c|c|c|c|c|}
\hline \multirow{3}{*}{$\begin{array}{l}\text { Years } \\
2001\end{array}$} & \multicolumn{6}{|c|}{ Root yield $\left(\mathrm{t} \mathrm{ha} \mathrm{C}^{-1}\right)$} & \multicolumn{6}{|c|}{ Sugar content $\left({ }^{\circ} \mathrm{S}\right)$} \\
\hline & \multicolumn{2}{|c|}{ Chiseling } & \multicolumn{2}{|c|}{ Plow+subsoil } & \multicolumn{2}{|c|}{ Plowing } & \multicolumn{2}{|c|}{ Chiseling } & \multicolumn{2}{|c|}{ Plow+subsoil } & \multicolumn{2}{|c|}{ Plowing } \\
\hline & 27.63 & $d$ & 30,92 & $\mathrm{~cd}$ & 28,16 & $\mathrm{~cd}$ & 12,2 & $\mathrm{fg}$ & 12,0 & $\mathrm{fg}$ & 11,6 & $\mathrm{fg}$ \\
\hline 2002 & 49.33 & $a b$ & 50,45 & a & 44,21 & b & 12,2 & $\mathrm{fg}$ & 11,4 & $\mathrm{~g}$ & 12,7 & $f$ \\
\hline 2003 & 21.00 & $\mathrm{e}$ & 21,21 & e & 19,00 & e & 17,0 & $\mathrm{~cd}$ & 18,5 & $a b$ & 17,6 & bc \\
\hline 2004 & 29.83 & $\mathrm{~cd}$ & 30,08 & $\mathrm{~cd}$ & 29,29 & $\mathrm{~cd}$ & 19,1 & a & 19,6 & a & 17,0 & $\mathrm{~cd}$ \\
\hline 2005 & 31.25 & $\mathrm{~cd}$ & 34,25 & c & 30,15 & $\mathrm{~cd}$ & 15,3 & $\mathrm{e}$ & 15,8 & de & 15,5 & e \\
\hline Mean & 31.81 & & 33,38 & & 30,16 & & 15,2 & & 15,4 & & 14,9 & \\
\hline
\end{tabular}

*In all tables, the means with the same letter are not significant differently at $\mathrm{P}<0,05$ according to the "t" test.

Table 2: Tillage effects on sugar yield

\begin{tabular}{lrlrc}
\hline \multirow{2}{*}{ Tillage } & \multicolumn{5}{c}{ Sugar yield } \\
\cline { 2 - 6 } & \multicolumn{3}{c}{ Theoretic } & \multicolumn{3}{c}{ White } \\
\cline { 2 - 6 } & 4.68 & $\left.\mathrm{ab} \mathrm{t} \mathrm{ha}^{-1}\right)$ & 3.74 & $\mathrm{ab}$ \\
\hline Chiseling & 4.93 & $\mathrm{a}$ & 3.92 & $\mathrm{a}$ \\
Plowing + subsoil & 4.37 & $\mathrm{~b}$ & 3.39 & $\mathrm{~b}$ \\
Plowing & 4.66 & 3.68 & \\
\hline Mean & 0.40 & 0.37 & \\
LSD $<0.05$ & & &
\end{tabular}


On the average for all years, sugar yield was better with plowing plus sub-soiling, without significant differences from chiseling which did not differ from shallow plowing (Table 2).

The difference of $0.5 \mathrm{t} \mathrm{ha}^{-1}$ of sugar justifies the higher tillage cost. Chiseling gave intermediate results and was interesting for the lower cost and time required. Tillage influenced the amount of amino nitrogen in the juice, but only in the 2004 sugar on the molasses was higher in shallow plowing, may be for lower water availability (Table 3).

Table 3: Qualitative traits of sugarbeet in combination of tillage and year

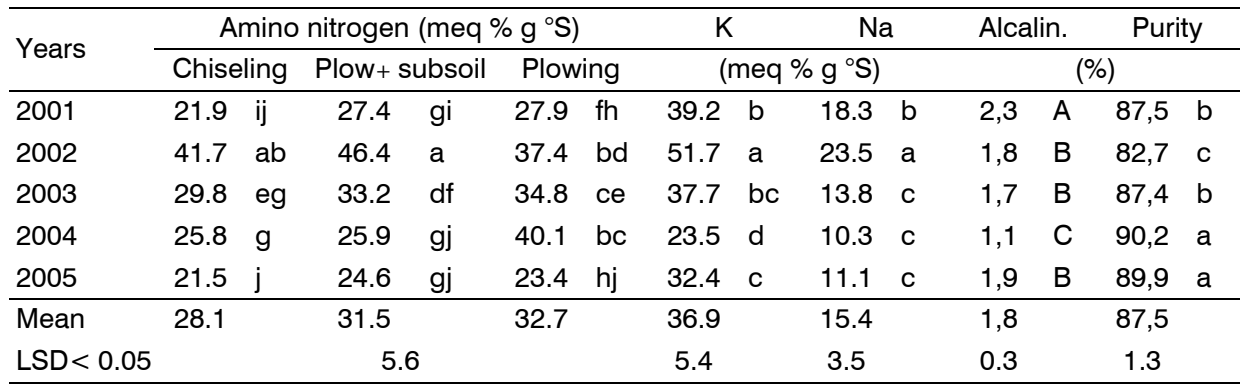

\section{Sorghum}

Chiseling gave the best yield in 2002 and the worst in 2003. This was probably related to soil moisture at the time of tillage and water availability in the cropping year. In 2002, with the best yield, tillage was done in 2001 with a very dry soil, because it is done after two months without rainfall, and during the cycle, after blooming, the crop had $60 \mathrm{~mm}$ of rainfall that allowed good grain filling, but negatively influenced chiseling for the following year.

The $60 \mathrm{~mm}$ rainfall totally refilled the water holding capacity of the soil, but, even if tillage was done after ten days, the water in the soil reduced the chisel and sub-soiling action resulting in greater compactness in the deeper layers, which were probably too wet.

A partially similar effect was also present in plowing plus sub-soiling where the sub-soiler had an action similar to the chisel.

\section{Sunflower}

The crop was less sensitive than the others to tillage and weather conditions. Yield was not influenced by tillage and in the worse year yield reduced (Table 4) only $20 \%$ of the overall mean and $30 \%$ less than the best value.

\section{Residual effect of summer crops tillage}

On the average for five years, wheat yielded less after sorghum ( $\left.4.57 \mathrm{t} \mathrm{ha}^{-1}\right)$ than after sunflower $\left(4.78 \mathrm{tha}^{-1}\right)$ or sugarbeet $\left(4.78 \mathrm{t} \mathrm{ha}^{-1}\right)$ with a difference of $4.4 \%$. The lower wheat yield after sorghum could be related to the rate of nitrogen applied, 
$150 \mathrm{~kg} \mathrm{ha}^{-1}$, chosen on the basis of the rule of regional low environmental impact. The nitrogen fertilizer applied was not enough for wheat and for the bacteria needed to decompose the sorghum residue. The residual effect of summer crops tillage was not significant neither alone nor combined with tillage for wheat. The 5-year average for wheat yield was, in fact, $5.0 \mathrm{t} \mathrm{ha}^{-1}$ after chiseling, $5.2 \mathrm{t} \mathrm{ha}^{-1}$ after plowing plus sub soiling, and $5.10 \mathrm{t} \mathrm{ha}^{-1}$ after shallow plowing.

Table 4: Yield and its components in sunflower

\begin{tabular}{|c|c|c|c|c|c|c|c|c|c|c|}
\hline \multirow{3}{*}{$\begin{array}{l}\text { Years } \\
2001\end{array}$} & \multirow{2}{*}{\multicolumn{2}{|c|}{$\frac{\text { Yield }}{\left(\mathrm{q} \mathrm{ha} \mathrm{h}^{-1}\right)}$}} & \multicolumn{2}{|c|}{ Plant height } & \multicolumn{2}{|c|}{ Head diameter } & \multirow{2}{*}{\multicolumn{2}{|c|}{$\begin{array}{c}\text { Stand } \\
\left(\mathrm{n} \mathrm{m}^{-2}\right)\end{array}$}} & \multirow{2}{*}{\multicolumn{2}{|c|}{$\begin{array}{c}\text { Thousand- seed weight } \\
\text { (g) }\end{array}$}} \\
\hline & & & \multicolumn{4}{|c|}{$(\mathrm{cm})$} & & & & \\
\hline & 25.9 & $a$ & 142 & $\mathrm{C}$ & 18.8 & $b$ & 4,6 & C & 52,6 & B \\
\hline 2002 & 27.4 & a & 157 & $b$ & 22.6 & a & 5,1 & $b$ & 61,7 & $A$ \\
\hline 2003 & 19.9 & $b$ & 152 & $b$ & 15.8 & d & 3,9 & d & 49,6 & B \\
\hline 2004 & 27.9 & a & 165 & $a$ & 17.1 & c & 5,1 & $b$ & 62,0 & A \\
\hline 2005 & 28.9 & a & 139 & C & 19.6 & b & 5,8 & a & 50,5 & B \\
\hline Mean & \multicolumn{2}{|c|}{26.0} & \multicolumn{2}{|c|}{151} & \multicolumn{2}{|c|}{18.8} & \multicolumn{2}{|c|}{4.9} & \multicolumn{2}{|c|}{55.3} \\
\hline
\end{tabular}

\section{Tillage for wheat}

Shallow plowing or minimum tillage with a cultivator, before planting wheat with a planter combined with a rotary hoe, after the three summer crops, did not produce differences in wheat yield (5.12 vs. $5.13 \mathrm{t} \mathrm{ha}^{-1}$ respectively, for plowing and cultivator) confirming that minimum tillage is enough for the crop.

\section{CONCLUSION}

The experiment confirmed the supposed higher need of sugarbeet for deep tillage, whereas sorghum and sunflower were less sensitive. With dry soil, chiseling was enough to prepare a seed bed compared with plowing plus sub-soiling, whereas with moist soil, shallow plowing gave the best results in sorghum but not in sugarbeet. Sorghum, even if in only one year, was more sensitive to tillage than sugarbeet.

Wheat yielded better after sugarbeet and sunflower than after sorghum, which is contrary to the report of Norwood (2000) who found better values after sorghum and corn than after sunflower. Lower wheat yield after sorghum could also be related to the amount of fertilizer applied (150 kg ha-1) which was not enough for the crop and decomposition of sorghum residue.

Plowing plus sub-soiling requires more energy and it could be justified only in sugarbeet. Minimum tillage was as efficient as shallow plowing for wheat seedbed preparation. 


\title{
ACKNOWLEDGMENTS
}

The authors thank Mauro Tiberi for soil classification and Mangoni Lorella for help in data recording.

\section{REFERENCES}

Laureti, D., Pieri, S., 2004. Risultati produttivi del girasole con lavorazioni ridotte del terreno. L'Informatore Agrario, Speciale Girasole. LX(10): 63-64.

Norwood, C.A., 2000. Dryland winter wheat as affected by previous crops. Agron. J. 92: 121127.

Roth, C.M., Shroyer, J.P., Paulsen, G.M., 2000. Allelopathy of sorghum on wheat under several tillage systems. Agron. J. 92: 855-860.

\section{REDUCCIÓN DE LABRANZA DEL SUELO EN ITALIA CENTRAL-ORIENTAL}

\author{
RESUMEN
}

La influencia de varios métodos de labranza del suelo (arado en la profundidad de $20-25 \mathrm{~cm}$, cincelado en la profundidad de $30 \mathrm{~cm}$ y arado en $20 \mathrm{~cm}$ más aradura de subsuelo en $50 \mathrm{~cm}$ ) combinado factorialmente con tres rotaciones bienales (trigo-remolacha azucarera; trigo-sorgo; trigo-girasol) fue investigado en el período entre 2000 y 2005 . La remolacha azucarera confirmó la supuesta necesidad para el arado profundo aumentada, mientras que sorgo y girasol eran menos sensibles. En el suelo seco, el cincelado fue suficiente para la preparación de presiembra en relación con la variante con el arado y aradura de subsuelo. En el suelo húmedo, el arado bajo dio buenos resultados con sorgo pero no con la remolacha azucarera. $\mathrm{El}$ arado más aradura de subsuelo, requieren más energía que puede justificarse únicamente en remolacha azucarera. El trigo dio mejor rendimiento después de remolacha azucarera y girasol que después de sorgo. La labranza mínima fue igualmente eficaz como el labrado bajo para la preparación de siembra para el trigo.

\section{DIMINUTION DES FAÇONS CULTURALES DANS L'ITALIE DU CENTRE EST}

\section{RÉSUMÉ}

L'effet de plusieurs façons culturales (labourage à une profondeur de 20$25 \mathrm{~cm}$, chiselage à $30 \mathrm{~cm}$ et labourage à $20 \mathrm{~cm}$ plus sous-solage à $50 \mathrm{~cm}$ ) combinées de manière factorielle à trois rotations biennales (blé- betteraves sucrière; blé- sorgho; blé- tournesol) a été observé au cours de la période 2000 - 2005. La betterave sucrière a confirmé le besoin supposé d'un travail du sol plus profond tandis que le sorgho et le tournesol se sont montrés moins sensibles. Pour le sol sec, le chiselage suffisait à préparer le semis comparativement à la variante labourage-sous-solage. Pour le sol humide, un labourage superficiel a donné de bons résultats avec le sorgho mais non avec la betterave sucrière. Le labourage plus sous-solage exige plus d'énergie et il n'est justifié que pour la betterave sucrière. Le blé a eu un meilleur rendement après la betterave sucrière et le tournesol après le sorgho. Un travail du sol minimal a été aussi efficace qu'un labourage superficiel dans la préparation du sol pour les semailles du blé. 